\title{
Surface Passivation Studies on n+pp+ Bifacial Solar Cell
}

\author{
Suhaila Sepeai, M. Y. Sulaiman, Kamaruzzaman Sopian, and Saleem H. Zaidi
}

Solar Energy Research Institute (SERI), Universiti Kebangsaan Malaysia, 43650 Bangi, Selangor, Malaysia

Correspondence should be addressed to Suhaila Sepeai, suhaila_sepeai@yahoo.com

Received 22 March 2012; Revised 31 July 2012; Accepted 3 August 2012

Academic Editor: Panagiotis Lianos

Copyright () 2012 Suhaila Sepeai et al. This is an open access article distributed under the Creative Commons Attribution License, which permits unrestricted use, distribution, and reproduction in any medium, provided the original work is properly cited.

\begin{abstract}
Bifacial solar cell is a specially designed solar cell for the production of electricity from both sides of the solar cell. It is an active field of research to make photovoltaics (PV) more competitive by increasing its efficiency and lowering its costs. We developed an $\mathrm{n}+\mathrm{pp}+$ structure for the bifacial solar cell. The fabrication used phosphorus-oxy-trichloride $\left(\mathrm{POCl}_{3}\right)$ diffusion to form the emitter and $\mathrm{Al}$ diffusion using conventional screen printing to produce the back surface field (BSF). The $\mathrm{n}+\mathrm{pp}+\mathrm{bifacial}$ solar cell was a sandwiched structure of antireflective coatings on both sides, Argentum (Ag) as a front contact and Argentum/Aluminum (Ag/Al) as a back contact. This paper reports the solar cell performance with different surface passivation or antireflecting coatings (ARC). Silicon nitride ( $\mathrm{SiN}$ ) deposited by Plasma-Enhanced Chemical Vapor Deposition (PECVD), thermally grown silicon dioxide $\left(\mathrm{SiO}_{2}\right), \mathrm{PECVD}-\mathrm{SiO}_{2}$, and $\mathrm{SiO}_{2} / \mathrm{SiN}$ stack were used as ARC. The efficiency obtained for the best bifacial solar cell having SiN as the ARC is $8.32 \%$ for front surface illumination and $3.21 \%$ for back surface illumination.
\end{abstract}

\section{Introduction}

Bifacial solar cell is a specially designed solar cell for the production of electricity from both sides of the solar cell. In bifacial solar cell allowance has to be made to allow absorption of light entering from the front and back sides. Since under ordinary circumstances the junction is located close to the front side, for rear illumination quantum efficiency is mostly realized from long wavelength. Thus, passivation and reflective indices of the rear side are important to the performance of the bifacial solar cell.

Cueves [1] reported that $H$. Mori 1966 developed the first bifacial solar cell by introducing a collecting $\mathrm{p}-\mathrm{n}$ junction on both sides of a silicon wafer. In order to compensate for the short minority carrier lifetime, Mori placed a second pn-junction closed to the rear surface. This improved the collection efficiency for long-wavelength photons. However, the need for a third metal contact makes such devices cumbersome. In 1972, Mandelkorn and Lamneck reported a bifacial solar cell with a homopolar $\mathrm{pp}+$ or $\mathrm{nn}+$ junction on the opposite surface of heteropolar pn junction [1]. The structure was known as bifacial Back Surface Field (BSF) cells. The origins of the original bifacial solar cell may be attributed to the drift field at the heavily doped rear surface which reduces recombination and improves open-circuit voltage $\left(V_{\mathrm{oc}}\right)$. Variations of bifacial BSF such as $\mathrm{n}+\mathrm{pp}+[2-4]$, $\mathrm{p}+\mathrm{nn}+[2,5], \mathrm{p}+\mathrm{np}+[6], \mathrm{n}+\mathrm{np}+[7]$, and $\mathrm{n}+\mathrm{pn}+[8]$ have all been reported.

The research on bifacial solar cell has since expanded by other researchers using wide range of device configurations in order to achieve higher efficiency. These include triode and Rear-Floating Emitter (RFE) [9], passivated emitter rear type (PERT) [3], and double-sided buried contact (DSBC) structures [10]. Methods that have been used in fabrication of bifacial solar cells include lithography [8], plasma-enhanced chemical vapor deposition (PECVD) $[4,11]$, screen-printed aluminum emitter [7], screen-printed boron and phosphorus pastes [12], spin on emitter [5], and boron and phosphorus gas diffusion [13]. Other than the use of thinner wafers, bifacial solar cells have other advantages including superior high temperature performance, lower metal usage, and enhanced power generation. A large number of bifacial solar cell improvements were made through surface texturing [8], buried contact [13], laser grooving [14], and electroplating [15].

The illumination received by bifacial solar cell is increased from the single facial solar cell of the same dimension. Optimum device processing should make bifacial solar 


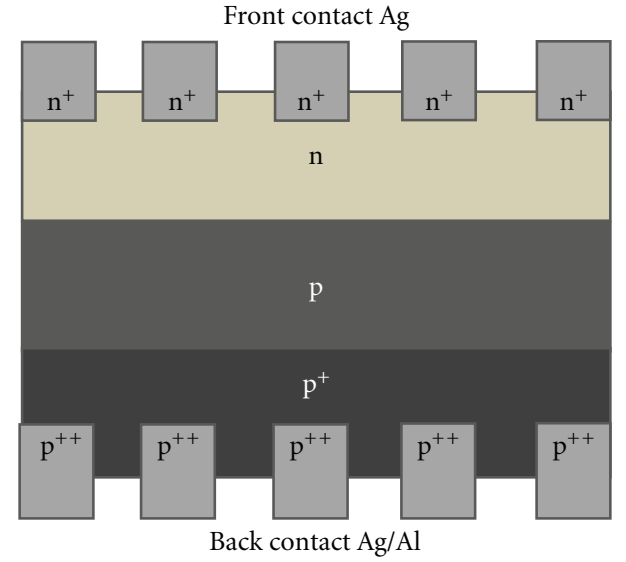

Figure 1: Bifacial solar cell with $\mathrm{n}+\mathrm{pp}+$ structure.

cell competitive to single-sided solar cell in terms of performance. Also, using thinner wafer helps decrease the cost of bifacial solar cell.

In this study, we design a bifacial solar cell with a simple fabrication process. We have modified our single facial solar cell design by incorporating aluminum firing and passivation on the rear side. In this way, we have included a $\mathrm{p}++$ layer. We expect the extra heavy doping at the rear contact of the bifacial solar cell will keep the electron away from the high recombination region. Besides, we develop an alternative technique to remove fired $\mathrm{Al}$ paste. Common techniques to remove aluminum are potassium bath [7] or nitric and fluoric acid dipping [8]. The effectiveness of passivation and antireflection coatings of $\mathrm{SiN}, \mathrm{SiO}_{2}$, and $\mathrm{SiN} / \mathrm{SiO}_{2}$ stacks are accessed.

\section{Materials and Methods}

Bifacial solar cells with a configuration of $n+p p+$ with Aluminium Back Surface Field (Al-BSF) were designed. The cell has screen-printed front surface Ag and back surface $\mathrm{Ag} / \mathrm{Al}$ contacts. Figure 1 is a schematic of the basic cell structure.

P-type $<100>$ Si wafers with resistivity ranging between $1 \mathrm{ohm}-\mathrm{cm}$ and $10 \mathrm{ohm}-\mathrm{cm}$ (with a doping density between $10^{15}$ and $10^{16}$ ) were used. The Si wafer was initially cleaned by dipping into solution of hydrofluoric acid (HF) and nitric acid $\left(\mathrm{HNO}_{3}\right)$ in a ratio of $1: 100$ for 10 minutes. After rinsing with deionized water, it was then dipped into $\mathrm{HF}$ and water $\left(\mathrm{H}_{2} \mathrm{O}\right)$ in a ratio of $1: 50$ for 1 minute. The wafer was then immersed in $10 \%$ potassium hydroxide $(\mathrm{KOH})$ at a temperature of $70^{\circ} \mathrm{C}$ for 5 minutes. Subsequently, the wafer was repeatedly cleaned in $\mathrm{HF}: \mathrm{H}_{2} \mathrm{O}$. The texturing process followed the cleaning procedure. The wafers were textured using a solution of $\mathrm{KOH}$, isopropyl alcohol (IPA), and water $\left(\mathrm{H}_{2} \mathrm{O}\right)$. After the texturing process, the wafers were subjected to the n-type diffusion using gas-source phosphorous oxychloride $\left(\mathrm{POCl}_{3}\right)$ at a temperature of $908^{\circ} \mathrm{C}$. The edges of the $\mathrm{Si}$ wafers were then mechanically diced to achieve edge isolation.
For bifacial solar cells with Al-BSF, Al pastes were screenprinted onto the back side of the Si wafer. The paste was annealed at $150^{\circ} \mathrm{C}$ for 10 minutes prior to firing at a temperature of $830^{\circ} \mathrm{C}$ in a rapid thermal annealing (RTA) furnace to form Al-diffused p+ layer. Excess $\mathrm{Al}$ was removed by soaking in $100 \%$ hydrochloric acid $(\mathrm{HCl})$ solution. In this way the $n+p p+$ structure was successfully fabricated.

We investigated three antireflection coating (ARC) and passivation structures. These are given in Figures 2(a), 2(b), and 2(c). For bifacial solar cell A, the thermally grown silicon dioxide $\left(\mathrm{SiO}_{2}\right)$ that was formed after the diffusion process was maintained on both sides as passivation and ARC, while, for cell $\mathrm{B}$, we removed the thermal oxide with Buffer Etch Oxide (BEO), after which we deposited the Silicon Nitride $(\mathrm{SiN})$ on both sides using PECVD at a temperature of $150^{\circ} \mathrm{C}$. For cell $\mathrm{C}$, we performed the $\mathrm{SiO}_{2} / \mathrm{SiN}$ stack process on the front and back sides. Besides the thermally grown $\mathrm{SiO}_{2}$, we also carried out a low-temperature $\mathrm{SiO}_{2}$ deposition using PECVD. We used a combination of silane and nitrous gas to obtain the PECVD-SiO 2 thin film.

Finally, the metallization processes were carried out using screen printing of $\mathrm{Ag}$ and $\mathrm{Ag} / \mathrm{Al}$ pastes by employing identical grid masks on the front and back surfaces, respectively. Screen-printed contacts were fired at $\sim 830^{\circ} \mathrm{C}$ to form front and back contacts.

The finished solar cells were experimentally analyzed by Light Current-Voltage (LIV) and Quantum Efficiency measurement systems using Keithley 237 current source meter. The Surface photovoltage properties of the front side of the bifacial solar cell were also examined.

\section{Results and Discussions}

Passivated interface reflects minority carriers but allows majority carriers to pass. Also, both emitter and base passivating layer of a bifacial solar cell has to be transparent to light and has a wider bandgap than silicon. A back surface field (BSF) is usually formed at the back of a solar cell to reflect minority carriers from combining at the rear. One way to achieve this is by increasing the doping of the surface field layer. However, a BSF is ineffective if the rear surface defect states are not passivated. In the present bifacial solar cell the front (emitter side) and back (base side) passivations are carried out using thin layers of $\mathrm{SiO}_{2}, \mathrm{SiN}$, and $\mathrm{SiN} / \mathrm{SiO}_{2}$ stack. In addition a BSF of $\mathrm{p}+$ region is also introduced at the back.

As mentioned above, SiN was deposited using PECVD and two depositions methods were used for $\mathrm{SiO}_{2}$ : thermally grown $\mathrm{SiO}_{2}$ and PECVD-SiO 2 . For the front side, the film was deposited on the emitter layer. Overall, two thermal annealing processes were independently carried out at $830^{\circ} \mathrm{C}$ through rapid firing; the first is $\mathrm{Al}$ firing to form the BSF and the other is the firing to form the front and back contacts. The effect of thermal treatment is shown to be conducive to surface and bulk passivation [9].

Figure 3 shows the minority carrier lifetime spectra of deposited PECVD-SiN, thermally grown $\mathrm{SiO}_{2}, \mathrm{PECVD-}$ $\mathrm{SiO}_{2}$, and $\mathrm{SiN} / \mathrm{SiO}_{2}$ stack on the emitter layer. The measurements were done under an operating voltage of $50 \mu \mathrm{V}$. 


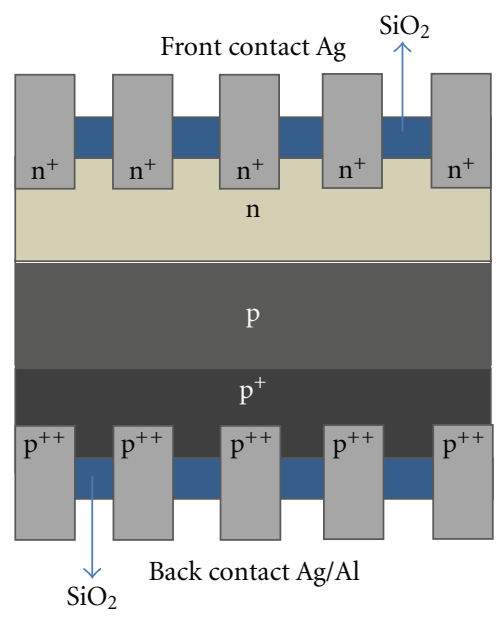

(a)

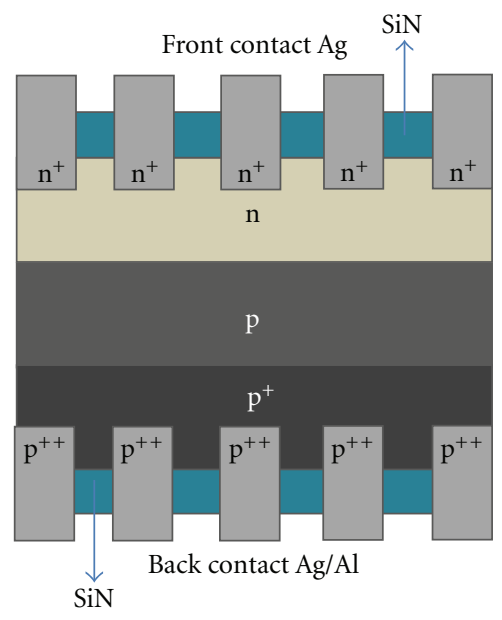

(b)

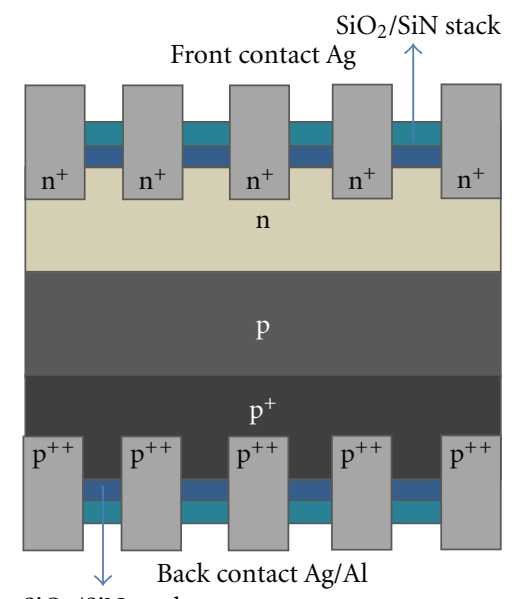

$\mathrm{SiO}_{2} / \mathrm{SiN}$ stack

(c)

FIGURE 2: The $\mathrm{n}+\mathrm{pp}+$ structure of bifacial Si solar cells with different ARC on both sides, namely, (a) thermally grown $\mathrm{SiO}_{2}$ or $\mathrm{PECVD} \mathrm{SiO}_{2}$, (b) PECVD SiN and (c) $\mathrm{SiO}_{2} / \mathrm{SiN}$ stack.

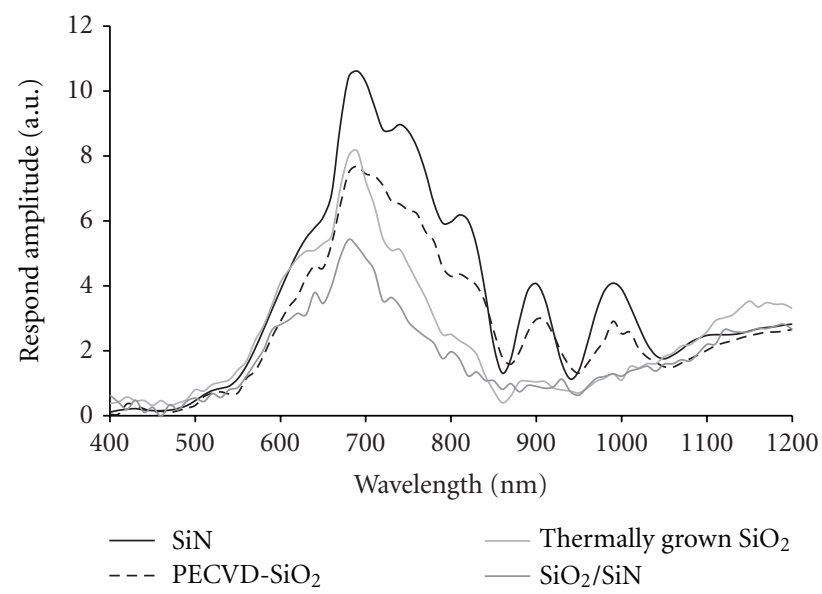

FIGURE 3: Results of Surface photovoltage (SPV) measurement of various antireflection coatings (ARCs).

SPV measures the minority carriers (i.e., electrons for $\mathrm{p}$ type silicon) collected on the surface of a thin film. From Figure 3, the respond amplitude for the ultraviolet region between $400 \mathrm{~nm}$ and $500 \mathrm{~nm}$ is seen to be small. Within these wavelengths, photons are absorbed in the emitter region. Electron in the emitter region is a majority carrier and for low-injection condition the Fermi level of the electron does not change much from the equilibrium position. Thus no photogenerated electron diffuses to the surface.

Between $500 \mathrm{~nm}$ and $700 \mathrm{~nm}$ photogenerated electrons that are produced in the junction and in the base close to the junction will diffuse to the surface. The quality of the passivation layer is measured by the increase in the number of electrons reaching the surface. The deposition induces passivation of silicon dangling bonds at the emitter surface and consequently the reduction of the interface state density that can trap electrons. Also, the existence of high positive fixed charge density at the surface causes a reduction in the majority hole carrier concentration at the surface by means of field-effect passivation. From Figure 3 it can be seen that $\mathrm{SiN}$ produces the best passivation followed by thermally grown $\mathrm{SiO}_{2}, \mathrm{PECVD} \mathrm{SiO} 2$, and $\mathrm{SiN} / \mathrm{SiO}_{2}$ stack in that order.

For wavelength greater than $700 \mathrm{~nm}$ the SPV respond amplitude decreases indicating less electrons reaching the surface. For absorption close to the back of the solar cell bulk recombination dominates if the diffusion length of the electrons is less than the thickness of the base.

It is informative to compare thermally grown $\mathrm{SiO}_{2}$ with PECVD-SiO ${ }_{2}$. In the visible-light range, both of them show similar performance, but they differ in the longer wavelength response. The thermally grown $\mathrm{SiO}_{2}$ has a faster decay rate in the wavelength 700-800 nm compared to PECVD-SiO ${ }_{2}$. The thermally grown process consists of the transportation of oxygen to the surface, diffusion of the oxygen through the already grown oxide, and finally the reaction of the oxygen with the silicon at the interface between silicon and silicon oxide. With growing oxide thickness, the growing rate slows down because the time of the diffusion through the oxide 


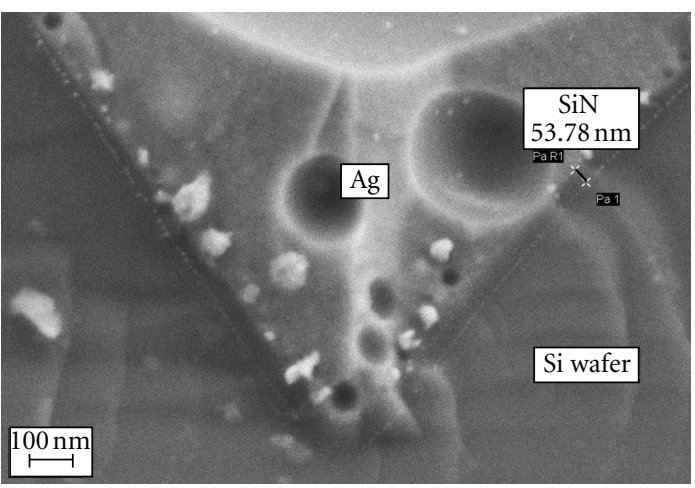

(a)

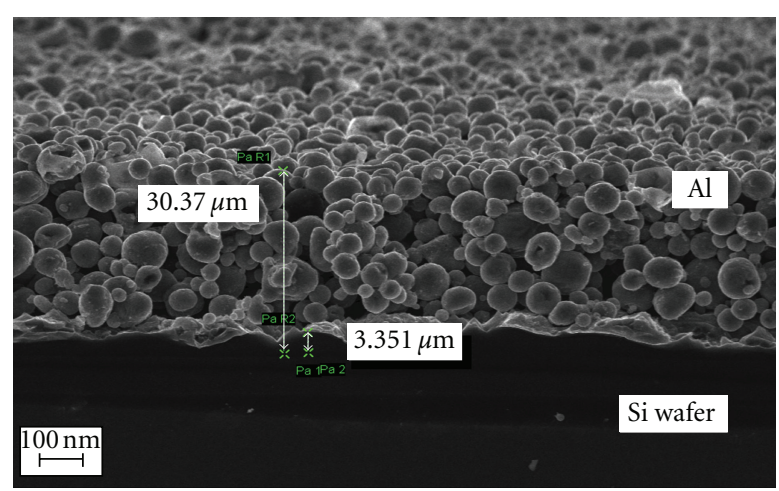

(b)

FIgURE 4: (a) SiN film on pyramidal textured Si wafer, (b) cross-sectional image of Al fired on the Si wafer.

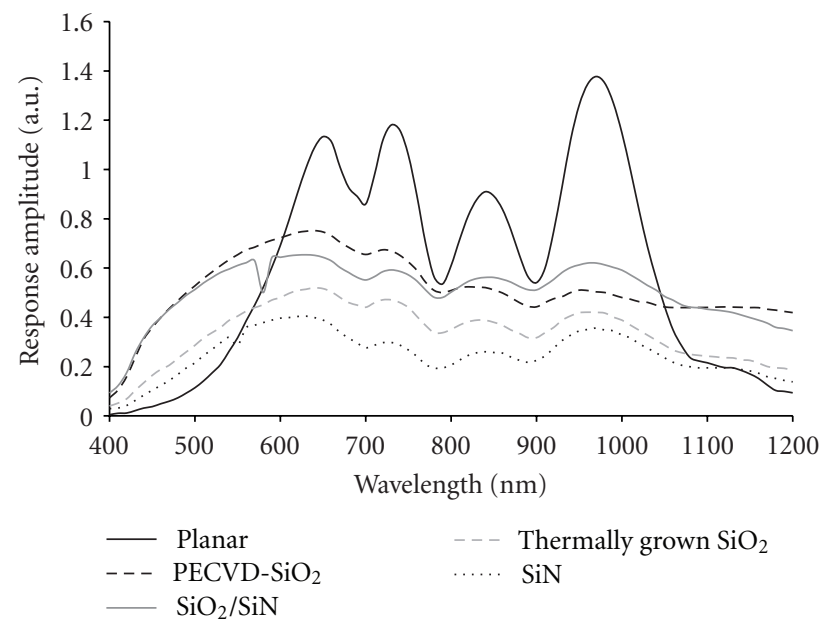

FIgURE 5: Reflectance spectra of $\mathrm{SiN}$, thermally grown $\mathrm{SiO}_{2}, \mathrm{PECVD}-\mathrm{SiO}_{2}$, and $\mathrm{SiO}_{2} / \mathrm{SiN}$ stack compared to planar wafer.

depends on its thickness. This process makes the degradation of thermally grown $\mathrm{SiO}_{2}$ faster than PECVD-SiO 2 .

Since thermally grown $\mathrm{SiO}_{2}$ and $\mathrm{PECVD}-\mathrm{SiO}_{2}$ show similar response in the visible light, we decided to use only thermally grown $\mathrm{SiO}_{2}$. The simplicity of surface passivation process by using thermal oxide is an added value to silicon solar cell processing [16]. Besides that, the surface is well passivated with lightly diffused phosphorus layer together with high-quality thermal oxide. By eliminating the use of PECVD process to deposit $\mathrm{SiO}_{2}$ the cost of fabrication can be kept low.

Figure 4(a) shows SEM images of SiN with a magnification of 50,000. From the figure, we see that $\mathrm{SiN}$ is deposited on the pyramid textured of the Si wafer with a thickness of $53.78 \mathrm{~nm}$. Figure 4(b) shows the cross-sectional image of $\mathrm{Al}$ on SiN film with a magnification of 1,000 . This characterization is done to study the Energy Dispersive XRay (EDX) profile of $\mathrm{Al}$ after the firing process to validate the punching of $\mathrm{Al}$ through the SiN layer to obtain the $\mathrm{p}+$ layer. From Table 1, we see that $\mathrm{Al}$ exists until Spectrum 4 of the profile. The deeper EDX spectrum shows less $\mathrm{Al}$. Thus, $\mathrm{Al}$ is
TABLE 1: EDX profile fired $\mathrm{Al}$ on the Si wafer.

\begin{tabular}{lccc}
\hline Spectrum & $\mathrm{Al}$ & $\mathrm{Si}$ & Total \\
\hline 1 & 89.96 & 10.04 & 100 \\
2 & 88.35 & 15.45 & 100 \\
3 & 84.55 & 11.65 & 100 \\
4 & 57.24 & 42.76 & 100 \\
5 & 0 & 100 & 100 \\
6 & 0 & 100 & 100 \\
7 & 0 & 100 & 100 \\
8 & 0 & 100 & 100 \\
9 & 0 & 100 & 100 \\
10 & 0 & 100 & 100 \\
\hline
\end{tabular}

able to punch through the ARC and diffuses into the Si wafer to form highly doped region.

Figure 5 shows the reflectance measurement of the various ARCs on planar $\mathrm{Si}$ wafer. From the figure, we can conclude that all ARCs show low reflectance compared to 
TABLE 2: Estimation of reflectivity from IV and QE experiments.

\begin{tabular}{lcccc}
\hline Bifacial cell & Position & $J_{\text {sc }}$ from IV $\left(\mathrm{mA} / \mathrm{cm}^{2}\right)$ & Photocurrent from QE $\left(\mathrm{mA} / \mathrm{cm}^{2}\right)$ & Reflectivity $\%$ \\
\hline A & Front & 26.75 & 20.2 & 5.4 \\
& Back & 13.25 & 20.7 & 59 \\
B & Front & 28.25 & 11.4 & 27 \\
& Back & 20.25 & 12.9 & 44 \\
C & Front & 26.5 & 6.9 & 51 \\
& Back & 21 & & 67 \\
\hline
\end{tabular}

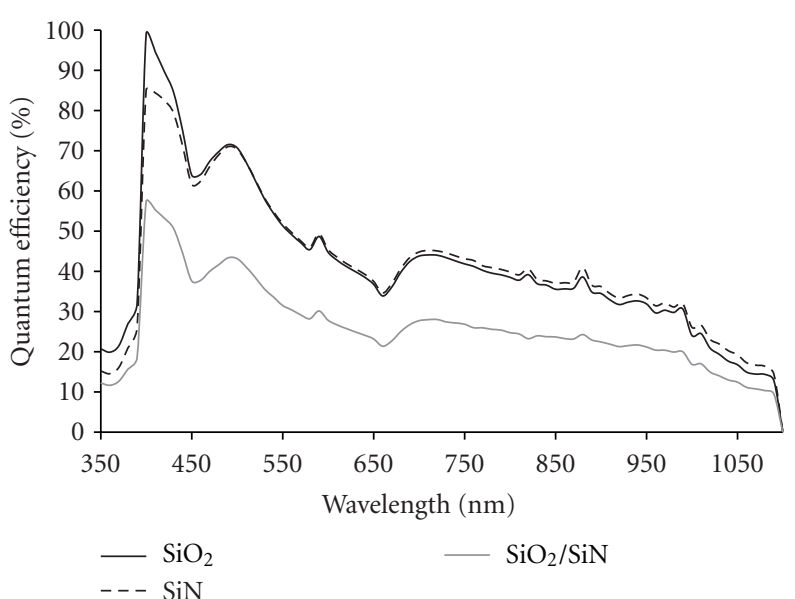

(a)

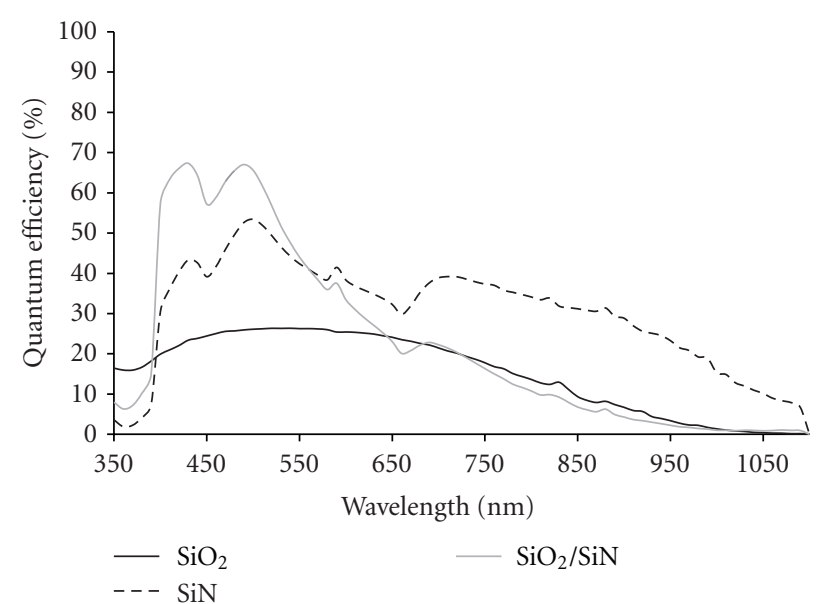

(b)

FIGURE 6: (a) Quantum efficiency for front illumination. (b) Quantum efficiency for back illumination.

planar wafer. The $\mathrm{SiO}_{2} / \mathrm{SiN}$ stack should show the lowest reflectance, but is actually higher than thermally grown $\mathrm{SiO}_{2}$ and PECVD-SiN due to nontextured surface. The combination of textured and ARC thin film should reduce reflection losses enhancing photon absorption.

For the bifacial solar cell the reflectivity does not differ much from the planar case shown in Figure 4. The reflectivity is derived from the IV measurement of the short-circuit current density and quantum efficiency measurement. These values are given in Table 2 . The reflectivity ranges between $24 \%$ and $67 \%$.

The percentage of photogeneration in solar cell can be determined by measuring the Quantum Efficiency (QE). Many factors affect the photogeneration. Figures 6(a) and 6(b) show the QE spectra for front and back illuminations of the bifacial solar cell having $\mathrm{SiO}_{2}, \mathrm{SiN}$, and $\mathrm{SiO}_{2} / \mathrm{SiN}$ stack ARC layers.

As shown in Figures 6(a) and 6(b) generally photogeneration decreases with increasing wavelength for both front and back illuminations. Also for front illumination the number of carriers generated is far less than one except for region in the lower part of the wavelength. Factors such as low absorption, high reflectivity of ARC, low field factor, high saturation current density, ineffective back surface field, and high bulk recombination all contribute to the degradation of the quantum efficiency. For front illumination the QE of
$\mathrm{SiO}_{2}$ and $\mathrm{SiN}$ ARCs are about the same. For stack ARC the $\mathrm{QE}$ is lower.

For back illumination the QE for SiN ARC solar cell is better although for low wavelength the QE of stack ARC is higher than $\mathrm{SiN}$. QE of $\mathrm{SiO}_{2}$ is the lowest. Thus, from the QE curve we have generated the photocurrent and this is given in Table 2. Together with the $J_{\mathrm{sc}}$ obtained from the IV results reported below, the reflectivity was deduced. It is shown that the $\mathrm{SiO}_{2}$ and $\mathrm{SiN}$ ARCs for front illumination show low reflectivity.

We now report the results of the current-voltage $(I-V)$ measurement of bifacial solar cells A, B, and C. Figure 7 shows the $I-V$ curve of these solar cells for (a) front and (b) rear side illuminations. For front side illumination, the $V_{\text {oc values are }} 0.492 \mathrm{~V}$ for solar cells A and B while for solar cell C it is $0.468 \mathrm{~V}$. The short-circuit current densities $\left(J_{\mathrm{sc}}\right)$ for front side illumination are $26.75 \mathrm{~mA} / \mathrm{cm}^{2}, 28.25 \mathrm{~mA} / \mathrm{cm}^{2}$, and $26.50 \mathrm{~mA} / \mathrm{cm}^{2}$ for solar cells $\mathrm{A}, \mathrm{B}$, and $\mathrm{C}$, respectively. For rear side illumination, the $V_{\text {oc }}$ for solar cell A remains at $0.492 \mathrm{~V}$, but for solar cells B and C, the $V_{\text {oc }}$ are $0.468 \mathrm{~V}$ and $0.444 \mathrm{~V}$, respectively. Device A with thermally grown $\mathrm{SiO}_{2}$ on both sides shows poor $J_{\mathrm{sc}}$ of $13.25 \mathrm{~mA} / \mathrm{cm}^{2}$ and is half the value of the front side. The SiN (solar cell B) and $\mathrm{SiO}_{2} / \mathrm{SiN}$ stacks (solar cell C) produce $J_{\mathrm{sc}}$ of $20.25 \mathrm{~mA} / \mathrm{cm}^{2}$, and $21.0 \mathrm{~mA} / \mathrm{cm}^{2}$, respectively.

The values of $J_{\mathrm{sc}}, V_{\mathrm{oc}}$, and $\mathrm{FF}$ for front and back illuminations of the bifacial solar cells are shown in Table 3 . 


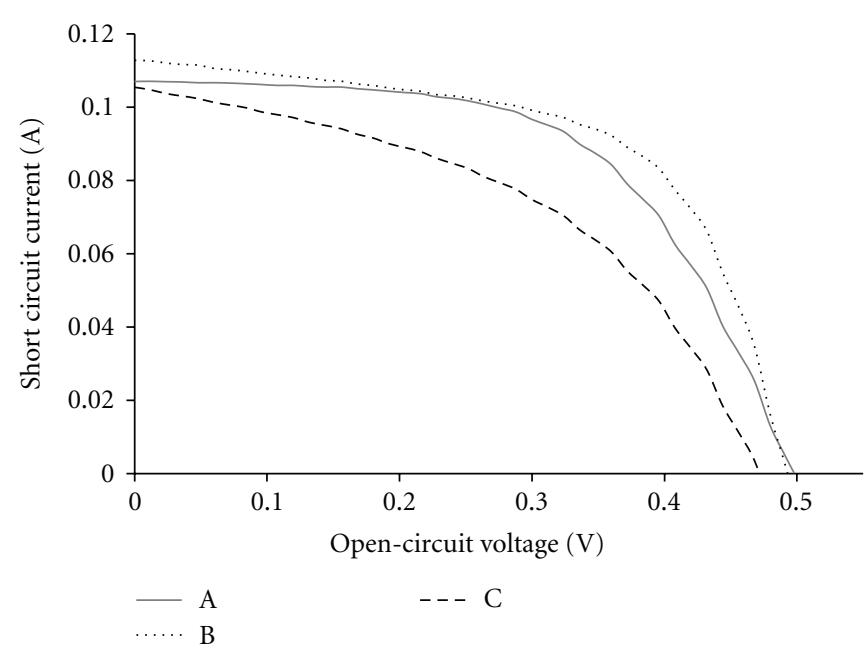

(a) Front

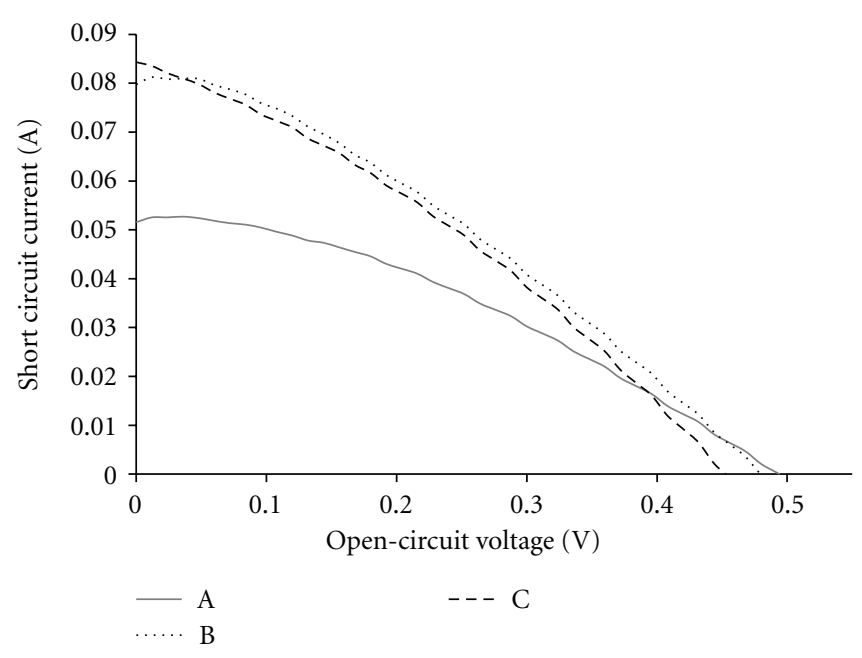

(b) Rear

FIgURE 7: $I$ - $V$ curves for front and rear illumination of bifacial solar cell for $\mathrm{SiO}_{2}, \mathrm{SiN}$, and $\mathrm{SiO}_{2} / \mathrm{SiN}$ stack ARC and passivation layers.

TABLE 3: Measured IV results of bifacial solar cell.

\begin{tabular}{lcccccc}
\hline Bifacial solar cell & Position & $V_{\mathrm{oc}}(\mathrm{V})$ & $J_{\mathrm{sc}}\left(\mathrm{mA} / \mathrm{cm}^{2}\right)$ & FF & Efficiency $(\%)$ & Saturation current density $J_{o} \times 10^{-10} \mathrm{~A} / \mathrm{cm}^{2}$ \\
\hline \multirow{2}{*}{ A } & Front & 0.492 & 26.75 & 0.57722 & 7.59 & 1.62 \\
& Back & 0.492 & 13.25 & 0.35889 & 2.34 & 0.80 \\
B & Front & 0.492 & 28.25 & 0.59834 & 8.32 & 1.71 \\
& Back & 0.468 & 20.25 & 0.33885 & 3.21 & 3.08 \\
C & Front & 0.468 & 26.50 & 0.46196 & 5.73 & 4.03 \\
& Back & 0.444 & 21.00 & 0.32878 & 3.07 & 8.05 \\
\hline
\end{tabular}

Also given are the values of the saturation current density $J_{o}$ calculated using the formula

$$
\ln \left(\frac{J_{\mathrm{sc}}}{J_{o}}\right)=\left(\frac{q V_{\mathrm{oc}}}{k T}\right)-1
$$

where $k$ is the Boltzmann's constant, $q$ is the electronic charge, and $T$ is the absolute temperature in Kelvin.

The substandard performance of the bifacial solar cell is attributed to many factors. One of the factors is the poor quality of ARC layers, thus giving rise to high reflectivity in particular for back illumination. This is clearly noticeable in the QE spectra. The effect related to the reflective indices of the ARC layer will have to be investigated further. The other factor is insufficient passivation. The saturation current density $J_{o}$ is of the order of $10^{-10} \mathrm{~A} / \mathrm{cm}^{2}$ which is higher compared to an optimum value of $10^{-14} \mathrm{~A} / \mathrm{cm}^{2}$. Besides that, the low fill factor due to ohmic losses as a result of a low conductivity of top semiconductor contributes the low efficiency of bifacial solar cell. Therefore, photogenerated carriers need to travel large lateral distances before being collected. The effect is manifested in high series resistance.

The $V_{\text {oc }}$ is also low as compared to the best $V_{\text {oc }}$ that can be obtained with good quality silicon solar cell, which is about $0.7 \mathrm{~V}$. This is attributed to ineffective back surface field and also poor passivation. Meanwhile, the low value of $J_{\mathrm{sc}}$ is attributed to poor passivation quality of the ARC layers. The high recombination velocity of minority carriers reduces $J_{\mathrm{sc}}$.
The $J_{\text {sc }}$ values are about half that can be achieved from the best solar cell which is about $43 \mathrm{~mA} / \mathrm{cm}^{2}$. From the results given in Table 3 , thermally grown $\mathrm{SiO}_{2}$ and $\mathrm{SiN}$ produce about the same passivation quality compared to $\mathrm{SiO}_{2} / \mathrm{SiN}$ stack. It is expected that the performance of the bifacial solar cell can be improved by varying the processing conditions such as the method of removing the fired Al to form the BSF.

\section{Conclusion}

Bifacial solar cells performance with different surface passivations was investigated. The best passivation scheme for antireflection coating (ARC) was thermally grown $\mathrm{SiO}_{2}$ and $\mathrm{SiN}$ since they show similar results. The front side of the bifacial solar cells produced better performance compared to the back side. For future research, we will develop a dry process to deposit a $\mathrm{p}+$ layer using boron solid source. We will also investigate the use of indium tin oxide (ITO) or silicon carbide ( $\mathrm{SiC}$ ) as ARC layers on both sides of the bifacial cells.

\section{Acknowledgments}

This work has been carried out with the support of the Malaysia Ministry of Science, Technology and Innovation (MOSTI) and Ministry of Higher Education (MoHE) under the TechnoFund and Fundamental Research Grant Scheme. 


\section{References}

[1] A. Cueves, "The early history of bifacial solar cell," in Proceedings of the 20th European Photovoltaic Solar Energy Conference, Barcelona, Spain, 2005.

[2] T. Buck, R. Kopecek, J. Libal et al., "Industrial screen printed ntype silicon solar cells with front boron emitter and efficiencies exceeding 17\%," in Proceedings of the 19th European PV Solar Energy Conference, p. 1255, Paris, France, 2004.

[3] J. Arumughan, R. Kopecek, T. Pernau, T. Buck, P. Fath, and K. Peter, "Realization of thin MC-silicon pert-type bifacial solar cells in industrial environments," in Proceedings of the IEEE 4th World Conference on Photovoltaic Energy Conversion, pp. 11031106, Honolulu, Hawaii, USA, May 2006.

[4] A. Kranzel, R. Kopecek, B. Terheiden, and P. Fath, "Bifacial solar cells on multicrystalline silicon," in Proceedings of the 15th International Photovoltaic Science and Engineering Conference (PVSEC-15 '05), pp. 885-886, Shanghai, China, 2005.

[5] H. Kerp, S. Kim, R. Lago et al., "Development of screenprintable contacts for $\mathrm{p}+$ emitters in bifacial solar cell," in Proceedings of the 21st European Photovoltaic Solar Energy Conference and Exhibition (EU PSEC '03), Dresden, Germany, 2003.

[6] V. D. Mihailetchi, L. J. Geerligs, Y. Komatsu et al., "High efficiency industrial screen printed n-type mc-Si with front boron emitter," in Proceedings of the 33rd IEEE Photovoltaic Specialist Conference, vol. 1, issue 2, pp. 1-5, 2007.

[7] B. Robert, J. Schmidt, M. Susanne, H. Bram, K. Erwin, and R. Brendel, "The ALU+ concept: N-type silicon solar cells with surface-passivated screen-printed aluminum-alloyed rear emitter," IEEE Transactions on Electron Devices, vol. 57, no. 8, pp. 1966-1971, 2010.

[8] A. Moehlecke, I. Zanesco, and A. Luque, "Practical high efficiency bifacial solar cells," in Proceedings of the IEEE World Conference Photovoltaic Energy Conversion, pp. 1663-1666, December 1994.

[9] H. Ohtsuka, M. Sakamoto, M. Koyama et al., "Effect of light degradation on bifacial Si solar cells," Solar Energy Materials and Solar Cells, vol. 66, no. 1-4, pp. 51-59, 2001.

[10] A. U. Ebong, C. B. Honsberg, and S. R. Wenham, "Fabrication of double sided buried contact (DSBC) silicon solar cell by simultaneous pre-deposition and diffusion of boron and phosphorus," Solar Energy Materials and Solar Cells, vol. 44, no. 3, pp. 271-278, 1996.

[11] B. Lenkeit, S. Steckemetz, F. Artuso, and R. Hezel, "Excellent thermal stability of remote plasma-enhanced chemical vapour deposited silicon nitride films for the rear of screen-printed bifacial silicon solar cells," Solar Energy Materials and Solar Cells, vol. 65, no. 1, pp. 317-323, 2001.

[12] J. Y. Lee and S. H. Lee, "Boron back surface field using spinon dopants by rapid thermal processing," Journal of the Korean Physical Society, vol. 44, no. 6, pp. 1581-1586, 2004.

[13] S. B. Ghozati, A. U. Ebong, C. B. Honsberg, and S. R. Wenham, "Improved fill-factor for the double-sided buriedcontact bifacial silicon solar cell," Solar Energy Materials and Solar Cells, vol. 51, no. 2, pp. 121-128, 1998.

[14] J. H. Guo and J. E. Cotter, "Laser-grooved backside contact solar cells with $680-\mathrm{mV}$ open-circuit voltage," IEEE Transactions on Electron Devices, vol. 51, no. 12, pp. 2186-2192, 2004.

[15] J. H. Guo and J. E. Cotter, "Metallization improvement on fabrication of interdigitated backside and double sided buried contact solar cells," Solar Energy Materials and Solar Cells, vol. 86, no. 4, pp. 485-498, 2005.

[16] T. Markvart, Solar Cells: Materials, Manufacture and Operation, Elsevier, 2005. 


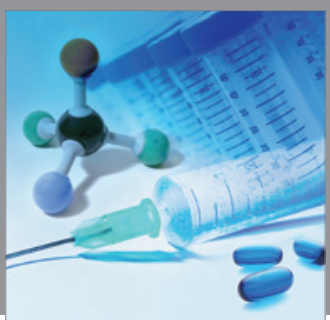

International Journal of

Medicinal Chemistry

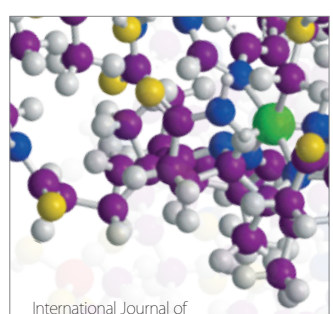

Carbohydrate Chemistry

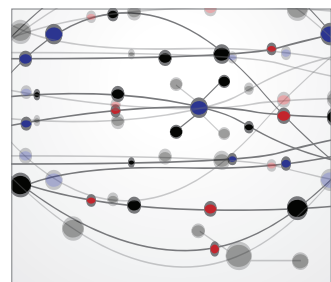

The Scientific World Journal
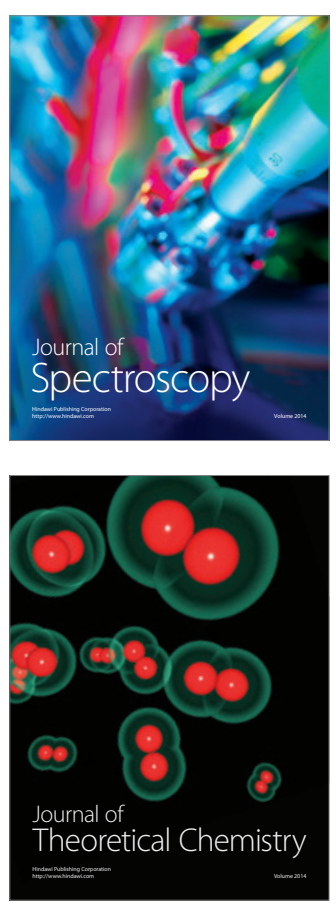
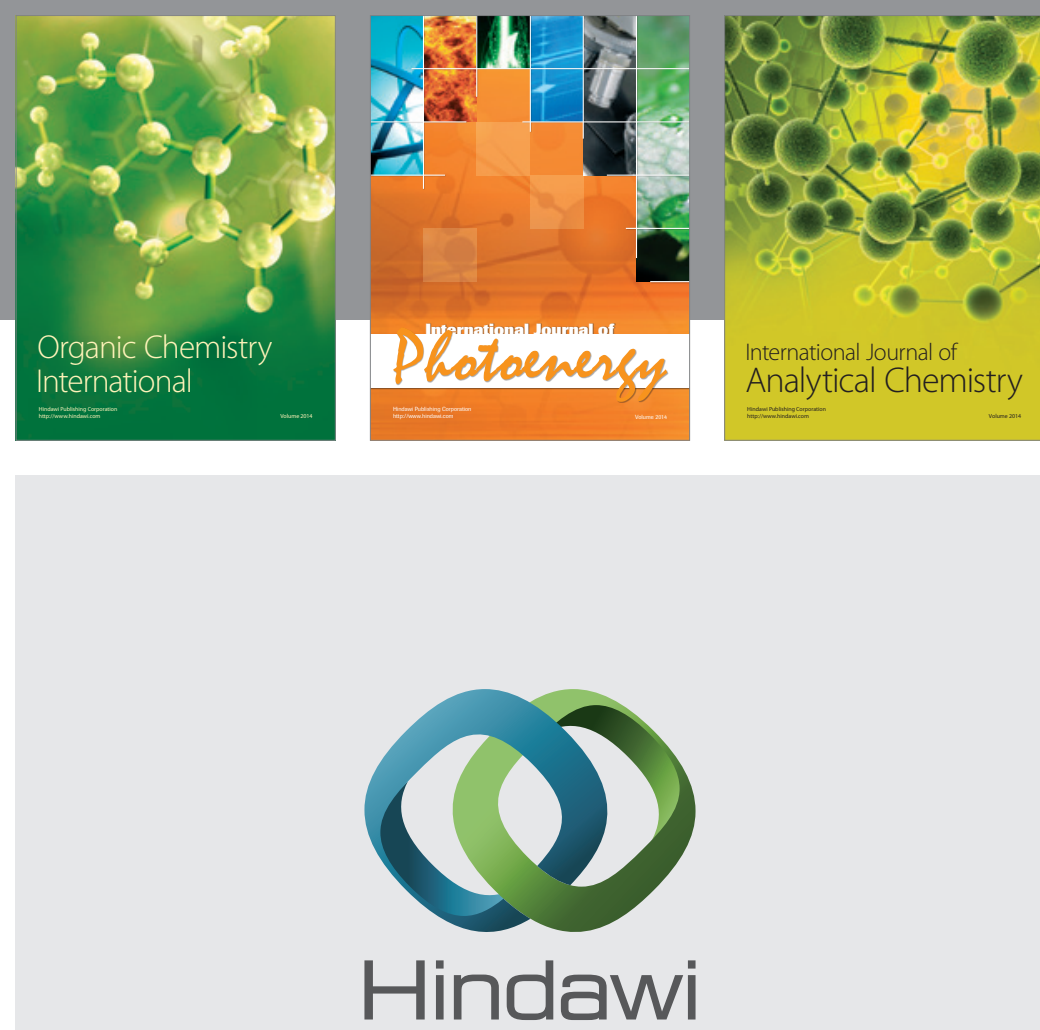

Submit your manuscripts at

http://www.hindawi.com
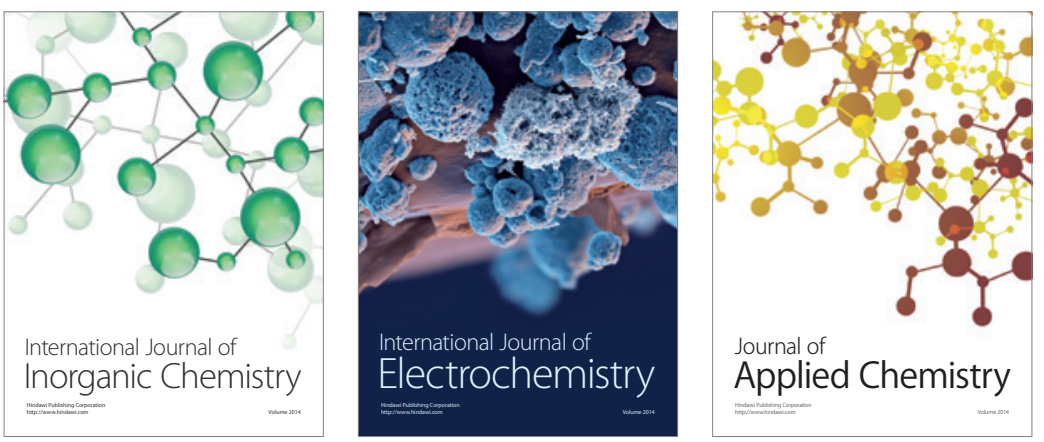

Journal of

Applied Chemistry
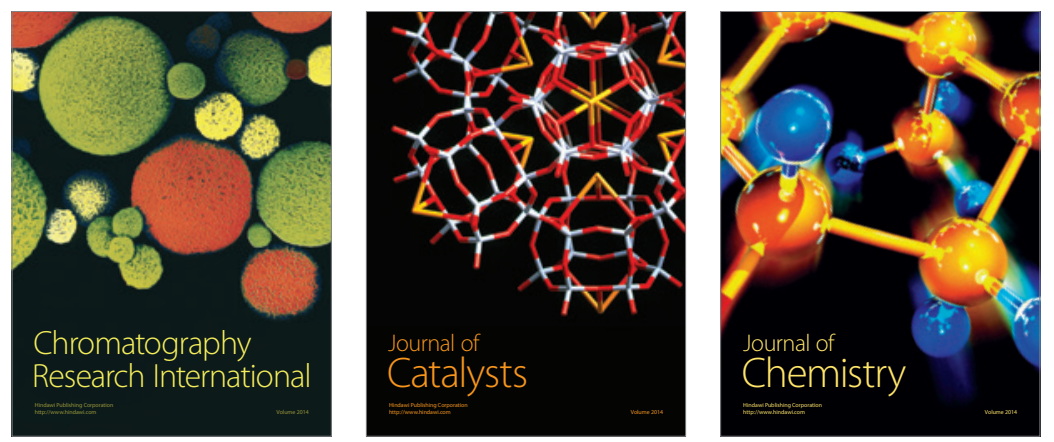
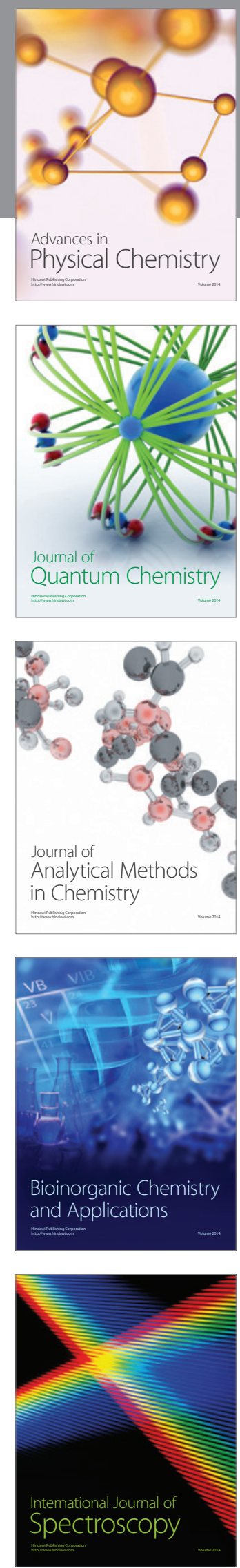